\title{
Formulasi Dan Uji Aktivitas Emulgel Minyak Ikan Gabus (Channa striata) Sebagai Penyembuh Luka Bakar
}

\author{
(Formulation and Activity Test of Snakehead (Channa striata) Oil as Burn Wound \\ Healing)
}

Nofriyanti, Novia Sinata, Aida Mistawati

Sekolah Tinggi Ilmu Farmasi (STIFAR) Riau, Pekanbaru, Indonesia, 28293

Email:nofriyanti@stifar-riau.ac.id

\section{Article Info:}

Received: 11 Februari 2020

in revised form: 16 Februari 2020

Accepted: 19 Agustus 2020

Available Online: 28 September 2020

Keywords:

Emulgel

Luka Bakar

Minyak

Ikan Gabus

Corresponding Author:

Nofriyanti

Sekolah Tinggi Ilmu Farmasi

(STIFAR)

Riau

Pekanbaru

28293

Indonesia

email: nofriyanti@stifar-riau.ac.id

\begin{abstract}
Burn wound often occur in various daily activities where the second-degree burn wound is the most common. Snakehead oil (Channa striata) contains fatty acids such as omega- 3 and omega- 6 which can accelerate the wound healing process. This study aims to determine the physical stability and effectiveness of emulgel preparations containing snakehead oil for 8 weeks of storage of the wound healing process, given topically to 5 groups of treated mice. Second degree burn wound was made on the skin of mice, then the wound was smeared with emulgel preparations and the healing process was observed for 21 days. Cork fish oil was formulated in several concentrations; 5\% (F1), 10\% (F2) and 15\% (F3). Organoleptic test results showed that all formulas formed as semisolid dosage form with a pale yellow color and distinctive smell of snakehead oil. The emulgel has homogenous state, not irritating effect and $\mathrm{pH}$ range of 5.3 to 5.7. The dosage which has a concentration of $15 \%$ possessed the smallest spread but had the longest adhesion. In the Freeze and Thaw stability test conducted at $4^{\circ} \mathrm{C}$ and $40^{\circ} \mathrm{C}$, the dosage remains stable with an increasing in globule size. Data analysis of the effectiveness of burn wound healing was done by twoway ANOVA statistical tests and continued with the Tukey test. The independent variable is the treatment group and the recovery time of mice while the dependent variable is the diameter of the burn wound. Statistical results showed that all formulas were different significantly $(\mathrm{p}<0.05)$ against negative controls indicating that they had effectiveness in wound healing. F3 had a better effectiveness of healing burn wound on the $15^{\text {th }}$ day with $100 \%$ healing percent compared with $\mathrm{F} 1$ and $\mathrm{F} 2$ on the $21^{\text {th }}$ day.
\end{abstract}




\section{ABSTRAK}

Luka bakar sering terjadi pada berbagai kegiatan sehari-hari dimana luka bakar derajat II adalah yang paling banyak ditemukan. Minyak ikan Gabus (Channa striata) memiliki kandungan asam lemak berupa omega-3 dan omega-6 yang dapat mempercepat proses penyembuhan luka. Penelitian ini bertujuan untuk mengetahui stabilitas fisik dan efektivitas sediaan emulgel yang mengandung minyak ikan gabus selama 8 minggu penyimpanan terhadap proses penyembuhan luka, yang diberikan secara topikal pada 5 kelompok mencit perlakuan. Dibuat luka bakar derajat II pada kulit mencit, kemudian luka tersebut diolesi dengan sediaan emulgel dan proses penyembuhannya diamati selama 21 hari. Minyak ikan gabus yang diformulasikan pada penelitian ini dirancang dalam beberapa konsentrasi: 5\% (FI), 10\% (F2) dan 15\% (F3). Secara organoleptis sediaan yang dihasilkan menghasilkan bentuk sediaan semipadat dengan warna kuning pucat dan berbau khas minyak ikan gabus. Emulgel memiliki susunan yang homogen, tidak menimbulkan efek mengiritasi dan rentang $\mathrm{pH} 5.3$ hingga 5.7. Sediaan yang memiliki konsentrasi $15 \%$ memberikan hasil daya sebar yang paling kecil namun memiliki daya lekat yang paling lama. Pada uji stabilitas Freeze and Thaw yang dilakukan pada suhu $4^{\circ} \mathrm{C}$ dan $40^{\circ} \mathrm{C}$ sediaan tetap stabil dengan peningkatan ukuran globul. Analisa data efektivitas penyembuhan luka bakar dilakukan dengan uji statistik ANOVA dua arah dan dilanjutkan dengan uji Tukey. Variabel bebas adalah kelompok perlakuan dan waktu sembuh mencit sedangkan variabel terikatnya adalah diameter luka bakar. Hasil statistic menunjukkan bahwa semua formula berbeda signifikan $(\mathrm{p}<0,05)$ terhadap kontrol negatif yang menandakan bahwa semua formula mempunyai efektivitas dalam penyembuhan luka. F3 (15\%) memiliki efektivitas penyembuhan luka bakar yang lebih baik pada hari ke-15 dengan persen penyembuhan 100\% dibandingkan dengan F1 dan F2.

Kata kunci: Emulgel, luka bakar, minyak ikan gabus, penyembuhan luka bakar.

\section{PENDAHULUAN}

Luka merupakan rusak atau hilangnya sebagian dari jaringan tubuh. Keadaan ini dapat terjadi karena adanya trauma benda tajam atau tumpul, perubahan suhu, zat kimia, ledakan, sengatan listrik maupun gigitan hewan (Pusponegoro, 2005). Adapun klasifikasi luka berdasarkan penyebab dasar dari luka adalah luka terbuka dan tertutup. Jenis luka yang dikategorikan sebagai luka terbuka yaitu luka insisi, luka laserasi, abrasi atau luka dangkal, luka bakar, luka tusuk, luka penetrasi, dan luka tembak (Nagori dan Solanki, 2011).

Luka bakar (combustio) adalah kerusakan atau kehilangan jaringan akibat kontak dengan sumber panas seperti api, air panas, bahan kimia, listrik, dan radiasi. Luka bakar merupakan suatu jenis trauma dengan morbiditas dan mortalitas yang tinggi (Moenadjat, 2003). Penyembuhan luka merupakan fenomena alami dimana tubuh dapat mengatasi kerusakan jaringan itu sendiri namun tingkat penyembuhannya relatif lambat dan probabilitas terinfeksi mikroba tinggi. Hal ini menyebabkan permintaan nutrisi yang cukup tinggi untuk mempercepat proses penyembuhan luka. Penanganan dalam penyembuhan luka bakar antara lain mencegah infeksi dan memberi kesempatan sisa-sisa sel epitel untuk berproliferasi dan menutup permukaan luka (Sabale et al, 2012). Pemberian terapi antimikroba topikal dalam bentuk salep atau cairan kompres/rendam umum dilakukan pada tatalaksana penanganan luka bakar.

Meskipun terdapat kemajuan yang luar biasa dalam industri farmasi, ketersediaan obat yang mampu merangsang proses perbaikan luka masih terbatas. Pengobatan tradisional banyak dilakukan karena lebih murah, lebih mudah didapat, dan efek samping yang rendah. Selain itu, masyarakat umumnya beranggapan bahwa penggunaan obat tradisional lebih aman dibandingkan dengan obat sintesis. Salah satu sumber bahan obat dari alam yang dapat mengobati luka bakar adalah ikan gabus (Channa striata) (Kumar dkk, 2007).

Secara empiris ikan gabus sering dikonsumsi sebagai lauk pasca melahirkan dan luka, baik luka pasca operasi maupun luka bakar (Yanti, 2012). Hal tersebut diduga karena ikan gabus mengandung asam lemak yang tinggi. Lemak atau lipid total yang terkandung pada ikan gabus berkisar 5,7-11,9 \% (Manan, 2007). Minyak ekstrak ikan gabus yang mengandung asam lemak tak jenuh omega-3 dan 
omega-6 merupakan nutrisi yang dapat mempercepat proses penyembuhan luka. Asam lemak omega-6 yang terdapat dalam minyak ikan adalah asam arakidonat yang merupakan substrat utama untuk sintesis eikosanoid yang memiliki efek pro dan antiinflamasi sehingga dapat mempercepat fase inflamasi (Collins dan Sulewski, 2011).

Hasil penelitian Gusdi (2012) menyatakan bahwa sediaan topikal gel ekstrak ikan gabus memiliki efektivitas penutupan luka sayat pada konsentrasi 5\% pada hari ke 9. Penelitian Sinambela (2012) menyatakan bahwa salep minyak ikan gabus memiliki efektivitas penutupan luka sayat pada konsentrasi $10 \%$ selama 7 hari.

Bentuk sediaan setengah padat seperti salep, krim, gel dan emulgel menjadi pilihan untuk efek penyembuhan yang lebih baik karena memungkinkan waktu kontak obat yang lebih panjang dan melindungi luka dari kontaminasi lingkungan luar. Emulgel merupakan suatu sediaan topikal yang tergabung dari emulsi dan gel. Sediaan emulgel terdiri dari gelling agent, fase minyak dan agen pengemulsi. Dengan adanya penambahan gelling agent didalam fase air maka dapat mengubah sistem emulsi menjadi emulgel. Emulgel sebagai suatu sediaan memiliki beberapa sifat yang baik antara lain tidak berminyak, mudah dioleskan, mudah tercuci, emollient, tidak meninggalkan bekas dan penampilannya yang menyenangkan (Singla et al, 2012).

Salah satu gelling agent yang dapat digunakan adalah Hidroksi Propil Metil Cellulosa (HPMC, dibandingkan dengan gelling agent lain, HPMC diketahui memiliki stabilitas yang baik bahkan setelah paparan panas dan kondisi lembab, di mana tidak ada perubahan yang signifikan yang diamati pada evaluasi homogenitas, $\mathrm{pH}$, kejernihan, tekstur profil analisis dan rheologi sifat gel HPMC (Dhawan et al, 2009).

Berdasarkan latar belakang diatas, penelitian ini dilakukan dengan memformulasi bentuk sediaan setengah padat yang berbeda, yaitu dalam bentuk emulgel yang menggunakan Hidroksi Propil Metil Cellulosa (HPMC) sebagai gelling agent. Penelitian ini bertujuan untuk mengetahui apakah minyak ikan gabus pada konsentrasi 5\%, 10\% dan 15\% yang diformulasikan dalam bentuk emulgel menggunakan HPMC sebagai gelling agent dapat memberikan stabilitas fisik yang baik sekaligus efektif sebagai penyembuh luka bakar.

\section{METODE PENELITIAN}

\section{Alat dan Bahan}

Alat yang digunakan dalam penelitian ini adalah timbangan analitik, kertas perkamen, mortir, stamfer, cawan porselin,beaker glass, gelas arloji, sudip, sendok, gelas ukur, kandang mencit, sarung tangan, kapas, logam besi, kasa steril dan jangka sorong.

Bahan yang digunakan dalam penelitian ini adalah minyak ikan gabus(CV. Eteris Nusantara), HPMC, natrium lauril sulfat, setil alkohol, propilenglikol, BHT, eter $10 \%$ dan aquadest.

\section{Hewan Uji}

Hewan uji yang digunakan adalah mencit jantan (Mus musculus) yang berumur 2-3 bulan dengan berat 20-30 gram sebanyak 20 ekor dalam keadaan sehat dan tidak cacat. Bahan yang digunakan untuk adaptasi mencit adalah makanan mencit (pellet) dan air minum. 


\section{Prosedur Kerja}

Tabel 1. Rancangan Formulasi Emulgel Minyak Ikan Gabus

\begin{tabular}{|c|c|c|c|c|}
\hline \multirow{2}{*}{ Bahan } & \multirow[b]{2}{*}{$\mathrm{F} 1$} & \multicolumn{2}{|c|}{ Formula \% } & \multirow{2}{*}{ Fungsi } \\
\hline & & $\mathrm{F} 2$ & F3 & \\
\hline Minyak Ikan gabus & 5 & 10 & 15 & Zat aktif \\
\hline HPMC & 3 & 3 & 3 & Gelling agent \\
\hline Natrium Lauril Sulfat & 0,5 & 0,5 & 0,5 & Surfaktan \\
\hline Setil Alkohol & 2 & 2 & 2 & Pengental \\
\hline Propilen glikol & 15 & 15 & 15 & Humektan, Pengawet \\
\hline $\mathrm{BHT}$ & 0,1 & 0,1 & 0,1 & Antioksidan \\
\hline Aquadest & ad 100 & ad 100 & ad 100 & Pelarut \\
\hline
\end{tabular}

\section{Prosedur Pembuatan Emulgel}

Pembuatan emulgel dilakukan sesuai dengan komposisi formula yang tertera pada tabel 1, masingmasing bahan ditimbang terlebih dahulu. Pembuatan emulsi yaitu fase minyak dibuat dengan mencampurkan setil alkohol dengan minyak ikan gabus di atas waterbath suhu $70^{\circ} \mathrm{C}$ dan ditambahkan BHT, lalu fase air dibuat dengan mencampurkan natrium lauril sulfat dengan propilen glikol. Fase minyak ditambahkan ke fase air pada suhu $70^{\circ} \mathrm{C}$ sambil terus distirrer dengan kecepatan $300 \mathrm{rpm}$ hingga terbentuk emulsi. Basis gel dibuat dengan mengembangkan HPMC dalam air panas sebanyak 20 kali berat HPMC, lalu diamkan selama 20-30 menit setelah itu digerus sampai terbentuk basis gel, kemudian emulsi ditambahkan kedalam basis gel dan digerus hingga homogen sampai terbentuk emulgel yang baik.

\section{Evaluasi Sifat Fisika Sediaan Emulgel}

\section{Uji Organoleptis}

Pengujian organoleptis dilakukan secara visual menggunakan panca indera untuk mendeskripsikan konsistensi, warna dan bau dari sediaan yang dilakukan setiap minggunya selama 8 minggu penelitian.

\section{Uji Homogenitas}

Pengujian homogenitas dilakukan dengan cara mengoleskan 1 gram emulgelpada sekeping kaca yang transparan, sediaan harus menunjukkan susunan yang homogen dan tidak boleh terlihat adanya butir-butir partikel yang kasar (Anonim, 2014).

\section{Uji pH}

Pengujian $\mathrm{pH}$ dilakukan menggunakan alat $\mathrm{pH}$ meter, yaitu dengan mencelupkan ke dalam sampel. $\mathrm{pH}$ meter yang digunakan sebelumnya telah dikalibrasi menggunakan larutan dapar standar. Pengujian dilakukan untuk melihat kesesuaian $\mathrm{pH}$ emulgel dengan $\mathrm{pH}$ fisiologis kulit yaitu 4,5-6,5 (Voight, 1994). Pengujian dilakukan setiap minggu selama 8 minggu penelitian.

\section{Uji Daya Sebar}

Daya sebar adalah kemampuan dari suatu sediaan untuk menyebar pada lokasipengaplikasiannya. Hal ini berhubungan dengan sudut kontak dari sediaan dengan tempat aplikasinya. Daya sebar merupakan salah satu karakteristik yang bertanggung jawab dalam keefektifan dalam pelepasan zat aktif dan penerimaan konsumen dalam penggunaan sediaan (Garg dkk, 2002). 
Pengujian dilakukan dengan meletakkan 0,5 gram emulgel di atas kertas grafik yang dilapisi plastik transparan, dibiarkan 60 detik kemudian dihitung diameter yang dihasilkan, kemudian ditutup lagi dengan pastik dan diberi beban anak timbangan mencapai 200 gram dibiarkan 60 detik (Voight). Dicatat diameter penyebaran emulgel setiap minggu selama 8 minggu penelitian.

\section{Uji Daya Lekat}

Uji daya lekat emulgel dilakukan untuk mengetahui kemampuannya bertahan pada permukaan kulit lebih lama. Semakin lama emulgel melekat pada kulit maka semakin banyak zat aktif yang diabsorbsi dan emulgel akan memberikan efek terapi yang lebih optimal (Voigt, 1994). Pengujian dilakukan dengan cara menimbang 0,5 gram emulgel yang diletakkan pada salah satu permukaan gelas objek kemudian tutup dengan gelas objek yang lain. Gelas objek ditindih dengan beban 500 gram selama 5 menit. Gelas objek yang berhimpit kemudian dipasang pada alat uji daya lekat dan bersamaan dengan pemberian beban 80 gram pada alat uji daya lekat, dihitung waktu yang diperlukan untuk 2 gelas objek hingga terlepas (Allen, 1998). Pengujian dilakukan setiap minggu selama 8 minggu penelitian.

\section{Uji Stabilitas Freeze and Thaw}

Pengujian stabilitas Freeze and Thaw bertujuan untuk mengethaui stabilitas fisik antara campuran fase air dan minyak yang dipengaruhi oleh suhu yang ekstrim. Siklus pengujian stabilitas antara fase air dan fase minyak dengan metodefreeze thaw pada sediaan emulgel dilakukan dengan 6 siklus untuk tiap formula. Setiap siklus diamati setelah 24 jam penyimpanan pada suhu $4{ }^{\circ} \mathrm{C}$ dan 24 jam pada suhu $40^{\circ} \mathrm{C}$ selama 12 hari. Siklus diamati apakah terjadi pemisahan fase atau tidak pada emulgel (Lachman et al., 1994).

\section{Uji Ukuran Globul}

Pengujian ini bertujuan untuk melihat stabilitas sediaan dengan melihat peningkatan ukuran globul. Peningkatan ukuran globul yang signifikan berarti bahwa formula sediaan emulgel minyak ikan gabus tidak stabil karena terjadi peningkatan laju sedimentasi (Sinko, 2006). Pengujian ukuran globul dilakukan dengan cara mengamati ukuran globul sediaan sebanyak 50 globul menggunakan mikroskop optik yang telah dipasang mikrometer dan telah dikalibrasi.

\section{Uji Iritasi}

Uji ini dilakukan untuk melihat keamanan sediaan sebelum digunakan dan untuk mengetahui respon tubuh manusia secara umum terhadap sediaan. Sediaan dikatakan baik bila tidak mengiritasi kulit selama 24 jam (Asmillyas, 2017). Pengujian dilakukan dengan uji tempel tertutup pada kulit manusia, caranya sediaan emulgel diambil 1 gram kemudian dioleskan pada lengan bagian dalam dengan ukuran $2 \times 2 \mathrm{~cm}$, ditutup dengan perban dan diplester dibiarkan selama 24 jam. Amati gejala yang timbul seperti kemerahan dan gatal-gatal pada kulit. Uji iritasi ini dilakukan terhadap tiga orang sukarelawan (Anonim, 1995).

\section{Pengelompokkan dan Perlakuan pada Hewan Uji}

Pada penelitian ini digunakan hewan mencit putih jantansebanyak 20 ekor yang diadaptasikan terlebih dahulu selama 7 hari, di mana hewan uji telah yang telah lolos uji kaji etik berdasarkan nomor surat : B/173/UN.19.5.1.1.8/UEPKK/2019. Selama masa adaptasi diberikan makanan dan minuman secukupnya. Setelah masa adaptasi, mencit diacak secara lengkap menjadi 5 kelompok perlakuan dengan setiap kelompok ada 4 ekor mencit.

P1 : Kelompok kontrol negatif luka bakar dengan penyembuhan alami

P2 : Kelompok perlakuan yang diberi basis

P3 : Kelompok perlakuan yang diberi F1 
P4 : Kelompok perlakuan yang diberi F2

P5 : Kelompok perlakuan yang diberi F3

Lokasi luka bakar yaitu di bagian punggung mencit. Tahap awal yaitu bulu pada punggung mencit putih yang akan dibuat luka bakar dicukur seluas $3 \times 3 \mathrm{~cm}$ sehari sebelum dilakukan luka bakar untuk mempermudah proses perlakuan luka bakar. Selanjutnya mencit dianastesi dengan eter $10 \%$ menggunakan kapas yang diberi eter dan ditutup dalam toples. Bagian punggung yang telah dicukur bulunya dibersihkan dengan alkohol 70\%, selanjutnya luka bakar dibuat dengan menggunakan lingkaran logam berdiameter $1,5 \mathrm{~cm}$ yang dipanaskan dalam air panas hingga suhu $85^{\circ} \mathrm{C}$ selama 15 menit. Logam panas tersebut ditempelkan pada bagian punggung mencit yang telah dicukur bulunya selama 20 detik hingga timbul luka berbentuk lingkaran dipunggung mencit (Jawetz dkk, 2012).

\section{Pengujian Aktivitas Penyembuhan Luka}

Pengujian dilakukan dengan mengoleskan emulgel minyak ikan gabus secara merata dua kali sehari setiap pukul 08.00 dan 15.00 WIB. Setelah dibuat luka bakar dan sebelum dioleskan emulgel, diukur terlebih dahulu diameter luka awal, kemudian emulgel dioleskan pada luka bakar yang dilakukan sejak hari ke-1 sampai dengan hari ke-21. Setiap hari pengujian diukur diameter luka menggunakan jangka sorong. Pengukuran dilakukan dengan mengukur empat ujung luka yang terbakar (gambar 1), sehingga didapatkan nilai diameter luka (Sumoza dkk, 2014) dengan rumus :

$$
\mathrm{dx}=\frac{d 1+d 2+d 3+d 4}{4}
$$

Keterangan : $\quad \mathrm{dx}=$ Diameter luka hari $\mathrm{ke}-\mathrm{x}(\mathrm{mm})$.

$\mathrm{d}(1,2,3$ dan 4$)=$ Diameter luka diukur dari 4 arah $(\mathrm{mm})$.

Persentase penyembuhan luka bakar (p\%) :

$$
\mathrm{p} \%=\frac{d 0-d p}{d 0} \mathrm{x} 100 \%
$$

Ket $: \mathrm{d} 0=$ diameter luka awal, $\mathrm{dp}=$ diameter perlakuan

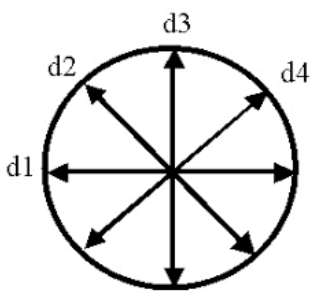

Gambar 1. Cara mengukur diameter luka (Sumoza dkk, 2014).

\section{Analisis Data}

Data pengurangan diameter luka bakar dilakukan uji hipotesis dengan menggunakan ANOVA dua arah. Jika hasil analisa bermakna kemudian dilanjutkan dengan Uji Tukey.

\section{HASIL DAN PEMBAHASAN}

\section{Hasil Evaluasi Sifat Fisika Sediaan Emulgel}




\section{a. Uji Organoleptis}

Hasil pengamatan pada minggu 1 dan 8 penyimpanan didapatkan hasil untuk F1, F2 dan F3 menghasilkan bentuk sediaan semi padat dengan warna kuning pucat dan berbau khas minyak ikan gabus.
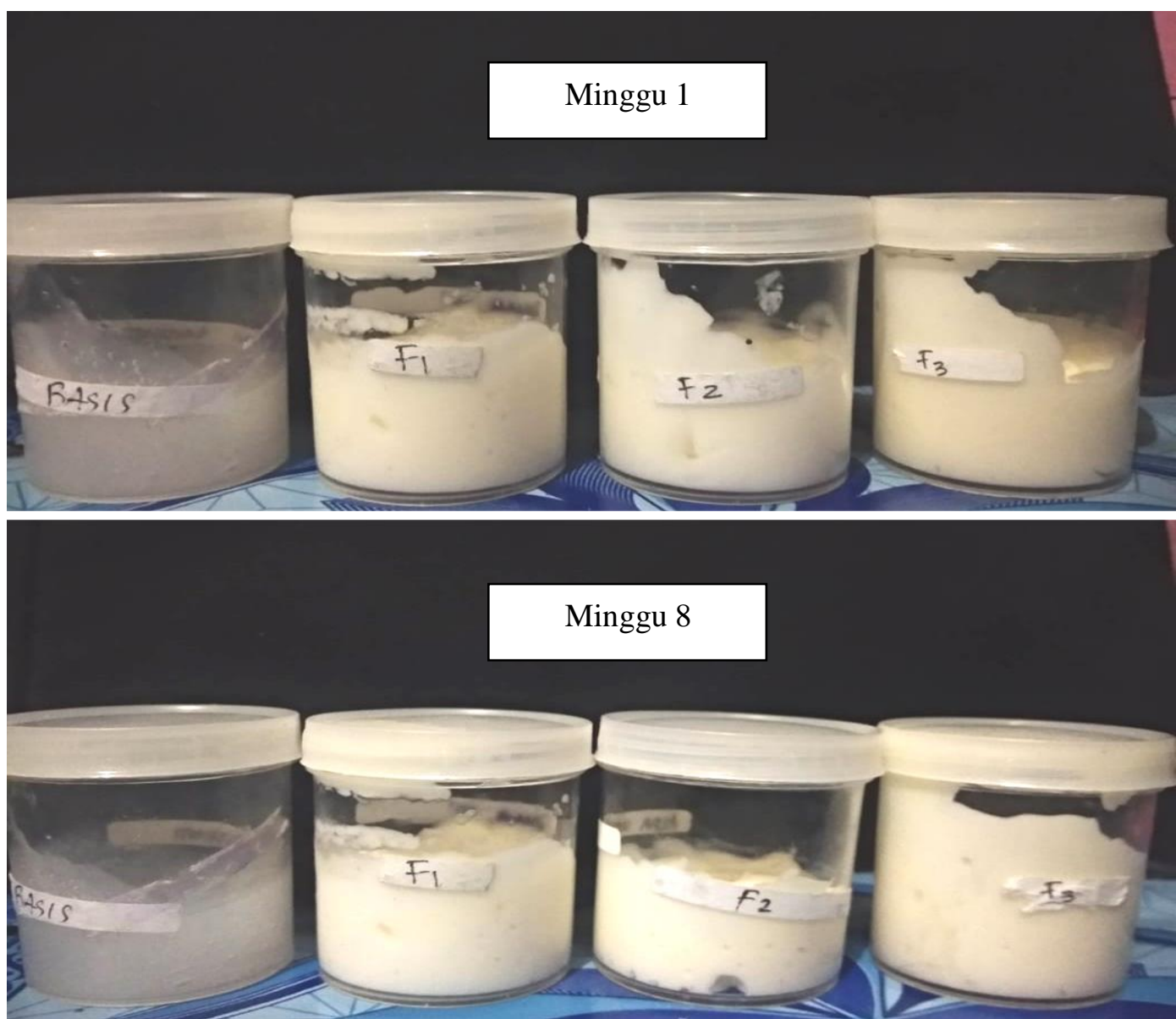

Gambar 2. Sediaan Emulgel Minyak Ikan Gabus Pada Minggu 1 dan Minggu 8 Penyimpanan

Berdasarkan gambar 2, terlihat bahwa sediaan gel yang dihasilkan tidak transparan, dengan bau khas minyak ikan gabus. Hal ini disebabkan karena koalesensi fase emulsi yang mengandung minyak ikan gabus lebih besar dibandingkan dengan basis gel, sehingga akan memudarkan kejernihan dari basis gel karena fase emulsi merupakan komponen cairan terbesar dalam formulasi (Agoes, 2012). Semakin tinggi konsentrasi minyak ikan gabus, maka warna emulgel akan semakin buram dan semakin berbau khas minyak ikan gabus.

\section{b. Uji Homogenitas}

Hasil pengamatan selama 8 minggu penyimpanan didapatkan sediaan emulgel dari F1, F2 dan F3 menunjukkan susunan yang homogen.

\section{c. Uji pH}

Hasil pengamatan pada minggu 1 dan minggu 8 penyimpanan didapatkan rentang $\mathrm{pH}$ 5,7-5,3 dan hasil ini masih sesuai dengan range $\mathrm{pH}$ kulit yaitu 4,5-6,5. 
Tabel 2. Hasil Pengukuran pH Sediaan Emulgel Minyak Ikan Gabus Pada Minggu 1 dan Minggu 8 penyimpanan

\begin{tabular}{lcc}
\hline \multirow{2}{*}{ Formula } & \multicolumn{2}{c}{ pH Minggu Ke- } \\
\cline { 2 - 3 } & $\mathbf{1}$ & $\mathbf{8}$ \\
\hline Basis & 5,6 & 5,3 \\
F1 $(5 \%)$ & 5,7 & 5,4 \\
F2 $(10 \%)$ & 5,5 & 5,3 \\
F3 $(15 \%)$ & 5,5 & 5,3 \\
\hline
\end{tabular}

Berdasarkan pengamatan tabel 2 di atas, terjadi penurunan nilai $\mathrm{pH}$ pada seluruh formula, hal ini memperlihatkan bahwa kondisi suhu selama penyimpanan dapat meningkatkan kadar asam atau basa dari komposisi sediaan (Putra dkk, 2014. Oleh karena itu, pengemasan sediaan dalam wadah gelap dapat menahan cahaya masuk secara langsung (Ansel, 2011).

\section{d. Uji Daya Sebar}

Hasil pengamatan pada minggu 1 dan minggu 8 penyimpanan menunjukkan bahwa setiap formula memberikan kemampuan daya sebar yang berbeda.

Tabel 3. Hasil Pengukuran Daya Sebar Sediaan Emulgel Minyak Ikan Gabus Pada Minggu Ke-1 dan Minggu Ke-8 Penyimpanan.

\begin{tabular}{|c|c|c|c|c|c|}
\hline \multirow{2}{*}{ Pengamatan } & \multirow{2}{*}{$\begin{array}{c}\text { Beban } \\
\text { (Gram) }\end{array}$} & \multicolumn{4}{|c|}{ Diameter Daya Sebar (cm) } \\
\hline & & Basis & F1 (5\%) & F2 $(10 \%)$ & F3 $(15 \%)$ \\
\hline \multirow{5}{*}{ Minggu ke-1 } & Tanpa Beban & 2,23 & 2,15 & 1,25 & 1,16 \\
\hline & 50 & 6,16 & 5,36 & 5,18 & 5,07 \\
\hline & 100 & 6,45 & 6,33 & 6,25 & 6,11 \\
\hline & 150 & 6,49 & 6,43 & 6,39 & 6,23 \\
\hline & 200 & 6,54 & 6,49 & 6,42 & 6,35 \\
\hline \multirow{5}{*}{ Minggu ke-8 } & Tanpa beban & 2,17 & 2,09 & 1,10 & 1,03 \\
\hline & 50 & 6,12 & 5,28 & 5,12 & 5,03 \\
\hline & 100 & 6,27 & 6,19 & 6,15 & 6,00 \\
\hline & 150 & 6,30 & 6,28 & 6,16 & 5,69 \\
\hline & 200 & 6,39 & 6,31 & 6,26 & 5,76 \\
\hline
\end{tabular}

Berdasarkan tabel 3 di atas, menunjukkan adanya perbedaan daya sebar dari tiap-tiap formula. Hal ini disebabkan karena variasi konsentrasi minyak ikan gabus yang digunakan. Di mana F3 dengan konsentrasi minyak paling tinggi (15\%) mempunyai daya sebar yang lebih kecil dibandingkan dengan F1 (5\%) dan F2 (10\%) karena memiliki konsistensi yang lebih kental. Pada kondisi ini berlaku suatu keadaan di mana semakin kental konsistensi suatu sediaan maka akan memberikan hasil diameter sebar yang semakin kecil.

\section{e. Uji Daya Lekat}

Hasil pengamatan pada minggu ke-1 dan minggu ke-8 minggu penyimpanan didapatkan daya lekat yang bervariasi dari setiap formula (basis, F1, F2 dan F3). 
Tabel 4. Hasil Pengukuran Daya Lekat Sediaan Emulgel Minyak Ikan Gabus PadaMinggu Ke-1 dan Minggu Ke-8 Penyimpanan.

\begin{tabular}{llcccc}
\hline \multirow{2}{*}{ Pengamatan } & Formula & \multicolumn{4}{c}{ Daya Lekat (detik) } \\
\cline { 3 - 6 } & & $\begin{array}{c}\text { Pengulangan } \\
\text { I }\end{array}$ & $\begin{array}{c}\text { Pengulangan } \\
\text { II }\end{array}$ & $\begin{array}{c}\text { Pengulangan } \\
\text { III }\end{array}$ & Rata-rata \\
\hline \multirow{2}{*}{ Minggu Ke-1 } & Basis & 43,1 & 46,22 & 42,10 & 43,81 \\
& F1 (5\%) & 49,15 & 48,10 & 49,17 & 48,80 \\
& F2 (10\%) & 58,14 & 58,22 & 56,31 & 57,55 \\
& F3 (15\%) & 72,10 & 72,40 & 71,42 & 71,97 \\
& Basis & 48,10 & 48,17 & 47,50 & 47,92 \\
Minggu Ke-8 & F1 (5\%) & 55,53 & 57,40 & 57,17 & 56,70 \\
& F2 (10\%) & 62,10 & 62,20 & 61,56 & 61,95 \\
& F3 (15\%) & 76,29 & 76,40 & 75,52 & 76,07 \\
\hline
\end{tabular}

Persyaratan daya lekat yang baik untuk sediaan topikal adalah lebih dari 4 detik (Tranggono dan Latifah, 2007), semakin lama daya lekat sediaan maka diharapkan akan semakin banyak zat aktif yang akan diabsorpsi sehingga dapat memberikan efek terapi yang optimal. Berdasarkan tabel 4 di atas, hasil daya lekat seluruh formula menunjukkan adanya perbedaan daya lekat dari tiap-tiap formula. Hal ini disebabkankarena variasi konsentrasi minyak ikan gabus yang digunakan. Dimana F3 dengan konsentrasi minyak paling tinggi (15\%) mempunyai konsistensi yang lebih kental, sehingga menghasilkan daya sebar yang lebih kecil tetapi memberikan daya lekat yang lebih lama dibandingkan dengan F1 (5\%) dan FII (10\%). Pada kondisi ini berlaku suatu keadaan di mana semakin kental konsistensi suatu sediaan, semakin kecil daya sebarnya, maka daya lekatnya akan semakin lama.

\section{f. Uji Stbilitas Freeze and Thaw}

Hasil pengamatan setelah 6 siklus pengujian dari setiap formula (basis, F1, F2 dan F3) menunjukkan sediaan emulgel minyak ikan gabus tetap stabil pada suhu pengujian $4^{\circ} \mathrm{C}$ dan $40^{\circ} \mathrm{C}$.
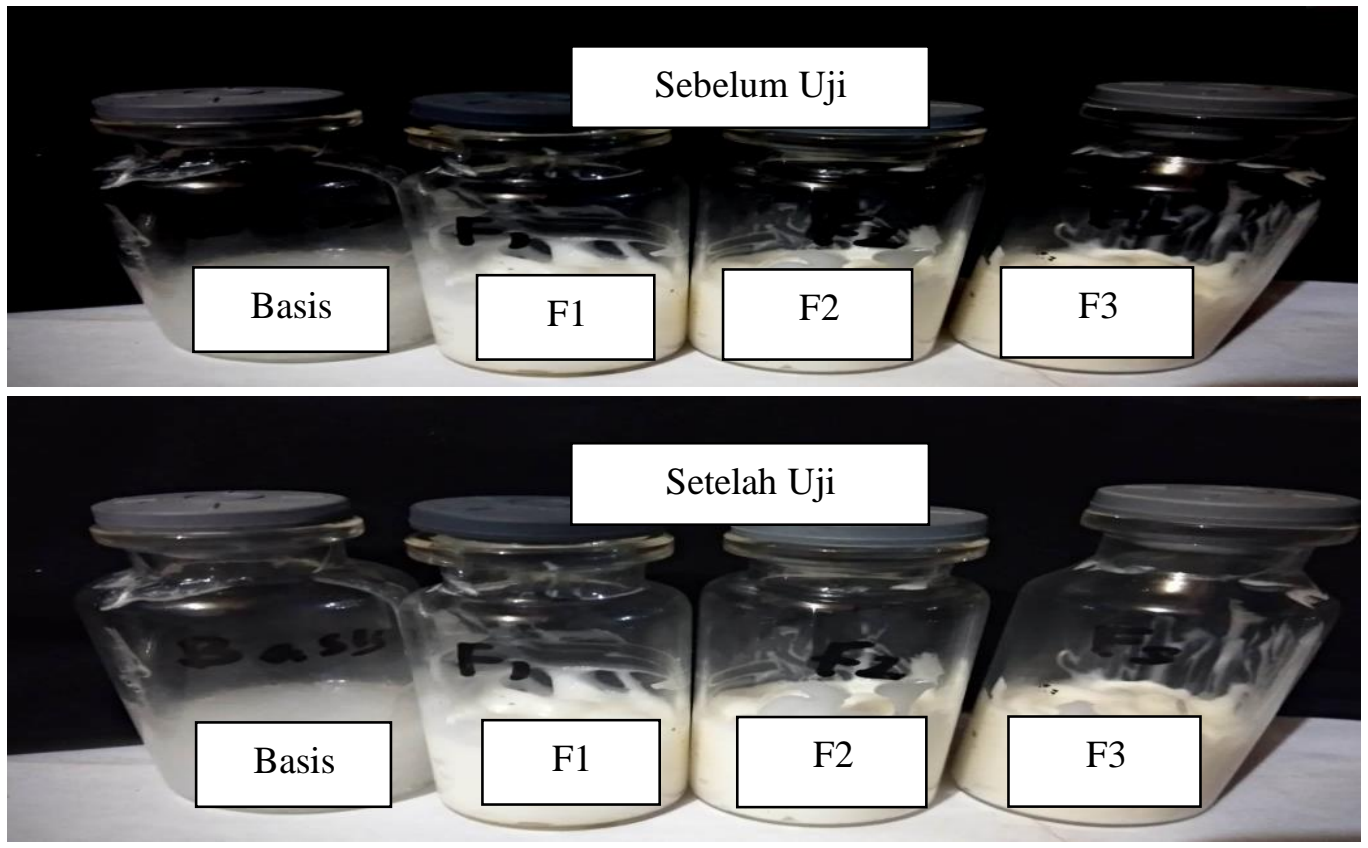

Gambar 3. Hasil Pengamatan Pengujian Stabilitas Freeze and Thaw Sedian Emulgel Minyak Ikan Gabus Sebelum dan Sesudah Pengujian. 
Berdasarkan gambar 3 di atas, pada pengujian yang akan mengukur stabilitas antara campuran fase minyak dan fase air yang dipengaruhi oleh perubahan suhu ekstrim seluruh formulasi memberikan hasil yang stabil, di mana tidak terjadi pemisahan antara fase air dan fase minyak. Hal ini berarti bahwa seluruh bahan yang digunakan dalam formulasi dapat bercampur dengan baik dan tetap stabil dengan adanya pengaruh perubahan suhu yang ekstrim.

\section{g. Uji Ukuran Globul}

Hasil pengamatan ukuran globul yang dilakukan sebelum dan sesudah pengujian stabilitas Freeze and Thaw menunjukkan adanya peningkatan ukuran globul selama penyimpanan.

Tabel 5. Hasil Pengamatan Ukuran Globul Sebelum danSesudah Pengujian Stabilitas Freeze and Thaw.

\begin{tabular}{ccc}
\hline \multirow{2}{*}{ Formula } & \multicolumn{2}{c}{ Rata- Rata Ukuran Globul $(\boldsymbol{\mu m})$} \\
\cline { 2 - 3 } & Sebelum & Sesudah \\
\hline F1 $(5 \%)$ & -0 & 2,55 \\
F2 $(10 \%)$ & -0 & 3,33 \\
F3 $(15 \%)$ & 2,66 & 5 \\
\hline
\end{tabular}

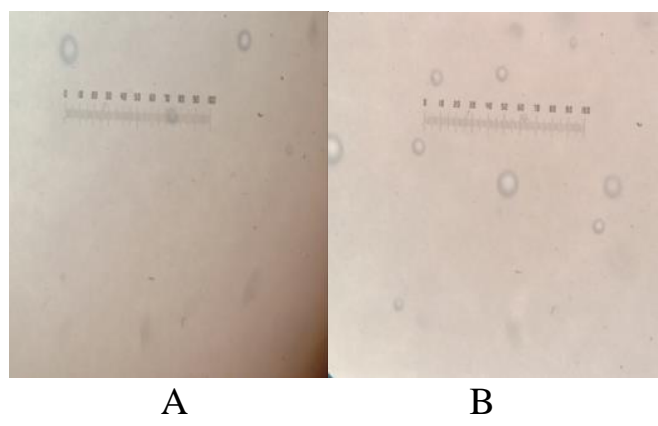

Gambar 4. Uji Ukuran Globul Pada F3 Sebelum (A) dan Sesudah Freeze and Thaw (B)

Setelah dilakukan uji stabilitas yang dipengaruhi oleh perubahan suhu yang ekstrim, selanjutnya seluruh sediaan diamati ukuran globulnya menggunakan mikroskop optik yang telah dipasang mikrometer dan telah dikalibrasi. Pengujian ini dilakukan untuk melihat apakah globul yang dihasilkan mempunyai ukuran yang sesuai dengan kriteria ukuran globul emulgel, yaitu 0,1-10 $\mu \mathrm{m}$ (Tri dkk, 2016). Hasil penelitian menunjukkan adanya kenaikan ukuran globul sebelum dan sesudah pengujian (Tabel 5 dan gambar 4). Emulgel dibentuk menggunakan sistem pembentukan emulsi. Emulsi merupakan suatu sistem yang tidak stabil secara termodinamika, dikarenakan adanya tegangan antar muka yang besar antara dua cairan yang tidak saling bercampur. Adanya energi bebas permukaan ini, menyebabkan kedua fase dalam sistem emulsi cenderung bergabung antar fase yang sejenis. Penggabungan ini nantinya akan menyebabkan pemisahan fase dalam emulsi. Untuk menghindari hal tersebut, maka salah satu cara yang dilakukan adalah dengan menambahkan bahan yang dapat menurunkan energi bebas dengan cara menurunkan tegangan antarmuka dari cairan-cairan tadi. Bahan ini yang disebut dengan emulgator. Namun, karena adanya efek penyimpanan dipercepat yang dilakukan dengan cara menyimpan sediaan pada suhu panas dan dingin, akan menyebabkan 
emulgator yang berfungsi untuk menstabilkan campuran kedua fase tidak dapat bekerja dengan baik lagi. Hal ini akan meningkatkan energi bebas dan tegangan antar muka. Sistem mempunyai cara untuk menstabilkan dirinya dengan cara penggabungan dari fase-fase yang sejenis. Penggabungan inilah yang biasa disebut flokulasi, yang merupakan salah satu gejala ketidakstabilan emulsi (Lachman dkk, 1994; Martin dkk, 1993). Pada F1 dan F2 didapatkan globul sebelum pengujian yang tidak terukur dengan baik. Hal ini disebabkan karena ketidakmampuan pengukuran oleh mikroskop okuler yang digunakan sehingga ukuran dituliskan dengan tanda minus (-). Peningkatan suhu penyimpanan menjadi $40^{\circ} \mathrm{C}$ secara signifikan akan menurunkan stabilitas emulsi, sedangkan penyimpanan pada suhu $4^{0} \mathrm{C}$ menyebabkan terjadinya pemisahan fase secara cepat karena penurunan kelarutan (Agoes, 2012). Namun, hasil pengamatan masih sesuai dengan range kriteria ukuran globul emulgel, sehingga walaupun terjadi peningkatan ukuran globul tetapi sediaan masih tetap stabil.

\section{h. Uji Iritasi}

Hasil pengamatan untuk setiap formula menunjukkan bahwa sediaan emulgel minyak ikan gabus tidak menimbulkan iritasi pada kulit dari 3 orang sukarelawan. Uji iritasi dimaksudkan untuk melihat respon kulit setelah dioleskan sediaan setelah 12 jam, di mana reaksi akan positif jika terjadi reaksi iritasi pada kulit, seperti kemerahan dan gatal-gatal.

\section{Hasil Uji Aktivitas Penyembuhan Luka}

Pada luka bakar derajat II dibuktikan dengan folikel rambut, kelenjar keringat dan kelenjar sebasea mengalami kerusakan dengan kulit yang terbakar berwarna putih pucat. Pada hasil uji aktivitas emulgel terhadap penyembuhan luka bakar derajat II ditandai dengan adanya pengurangan diameter luka bakar pada bagian punggung mencit yaitu adanya pengelupasan keropeng pada punggung mencit dan terjadi penutupan luka. Selain ditandai dengan pengurangan diameter luka yang menyatakan terjadinya proses penyembuhan, kondisi lainnya yang mengalami pemulihan adalah kondisi peradangan yang ditandai dengan berkurangnya warna merah dan bengkak pada bekas perlukaan. Kondisi pemulihan selanjutnya adalah terjadi proses penutupan luka yang terjadi sebagai reaksi sel-sel epitel bagian basal akan bermitosis dan selanjutnya sel-sel anak akan bermigrasi menyeberangi daerah luka untuk menyambungkan permukaan luka (Abdurrahmat, 2014). Fase inflamasi merupakan fase awal penyembuhan luka, di mana kondisi kulit terlihat kemerahan disekitar luka, edema dan cairan pada luka. Kondisi ini terjadi pada hari ke-0 hingga hari ke-6. Pada hari ke-6 terjadi respon segera setelah terjadi luka berupa pembekuan darah untuk mencegah kehilangan platelet, di mana terlihat bekas luka memutih dan mengering yang terlihat jelas pada F3. Pada fase proliferasi yaitu fase kedua, dimana akan dijumpai jaringan granulasi pada kulit yang tejadi setelah 14 hari. Jaringan fibroblast akan bermitosis membentuk kisi-kisi dari migrasi sel, yang selanjutnya akan memulai sintetis kolagen yang akan menggantikan jaringan ikat di daerah luka, di mana pada tabel 6 terlihat terjadinya pengurangan diameter luka pada hewan uji. Fase penyembuhan terakhir adalah fase maturasi, di mana mulai terlepasnya keropeng dari luka yang terjadi pada hari ke-21 (gambar 5). Setelah 3 minggu terjadinya luka, fibroblast yang telah menjadi kolagen akan mulai terkelupas dari luka. Asam lemak yang terdapat dalam minyak ikan gabus, yaitu omega-3 dan omega-6 berperan dalam proses penyembuhan luka. Asam lemak berperan dalam sistem kekebalan tubuh yaitu dalam proses pembentukan kolagen dan jaringan epitel pada luka. Pembentukan kembali jaringan epitel dalam penyembuhan luka juga dipercepat oleh pengaruh pengaplikasian secara topikal dengan manfaat pembersihan luka secara cepat hingga meminimalkan bekas luka (Abdurrahmat, 2014). Hasil penelitian menunjukkan F3 (15\%) telah mencapai $100 \%$ penyembuhan luka pada hari ke-15 pengujian, sedangkan F1 dan F2 baru mecapai 100\% penyembuhan luka pada hari ke-21 (gambar 6). 


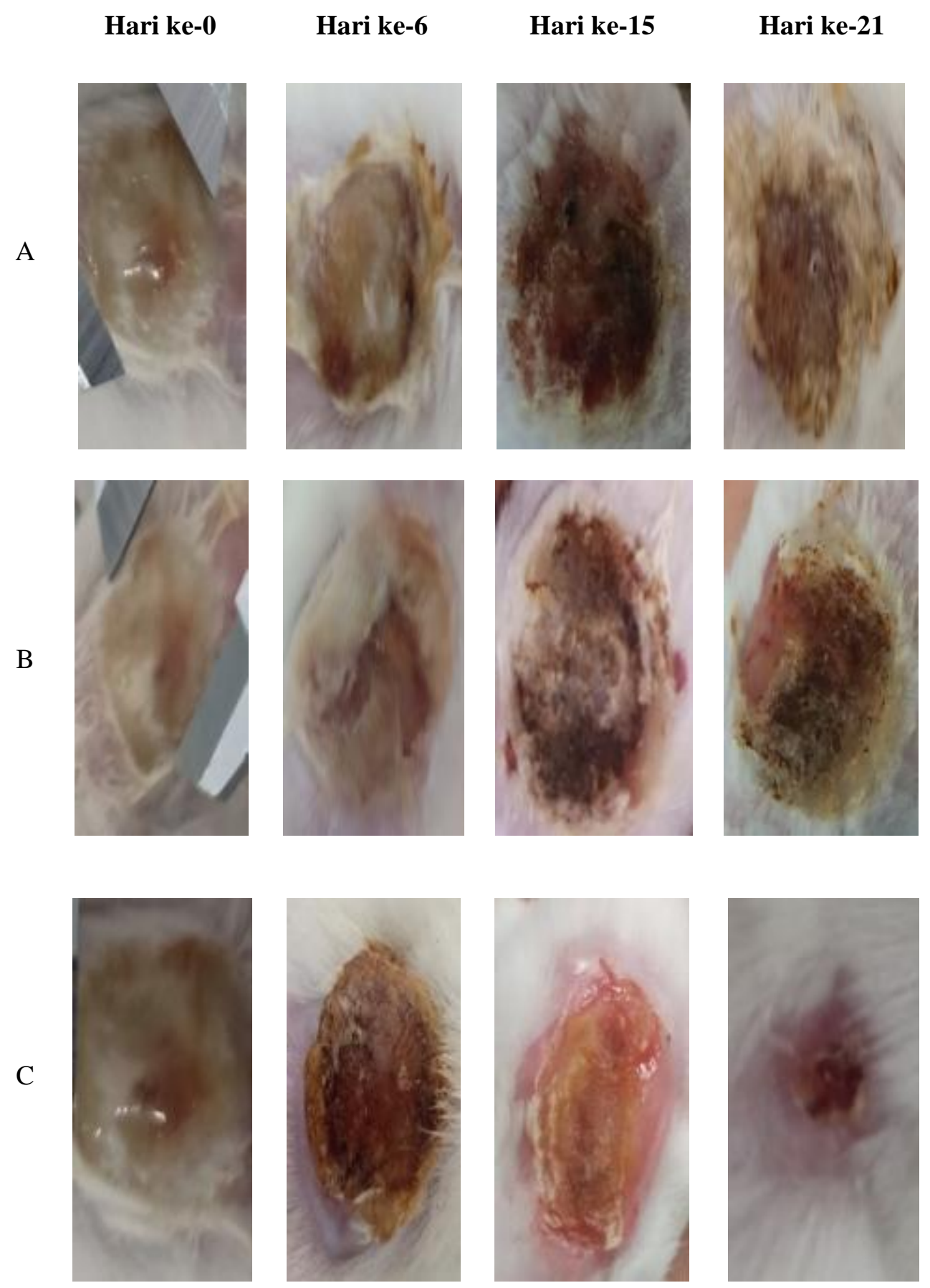


$\mathrm{D}$
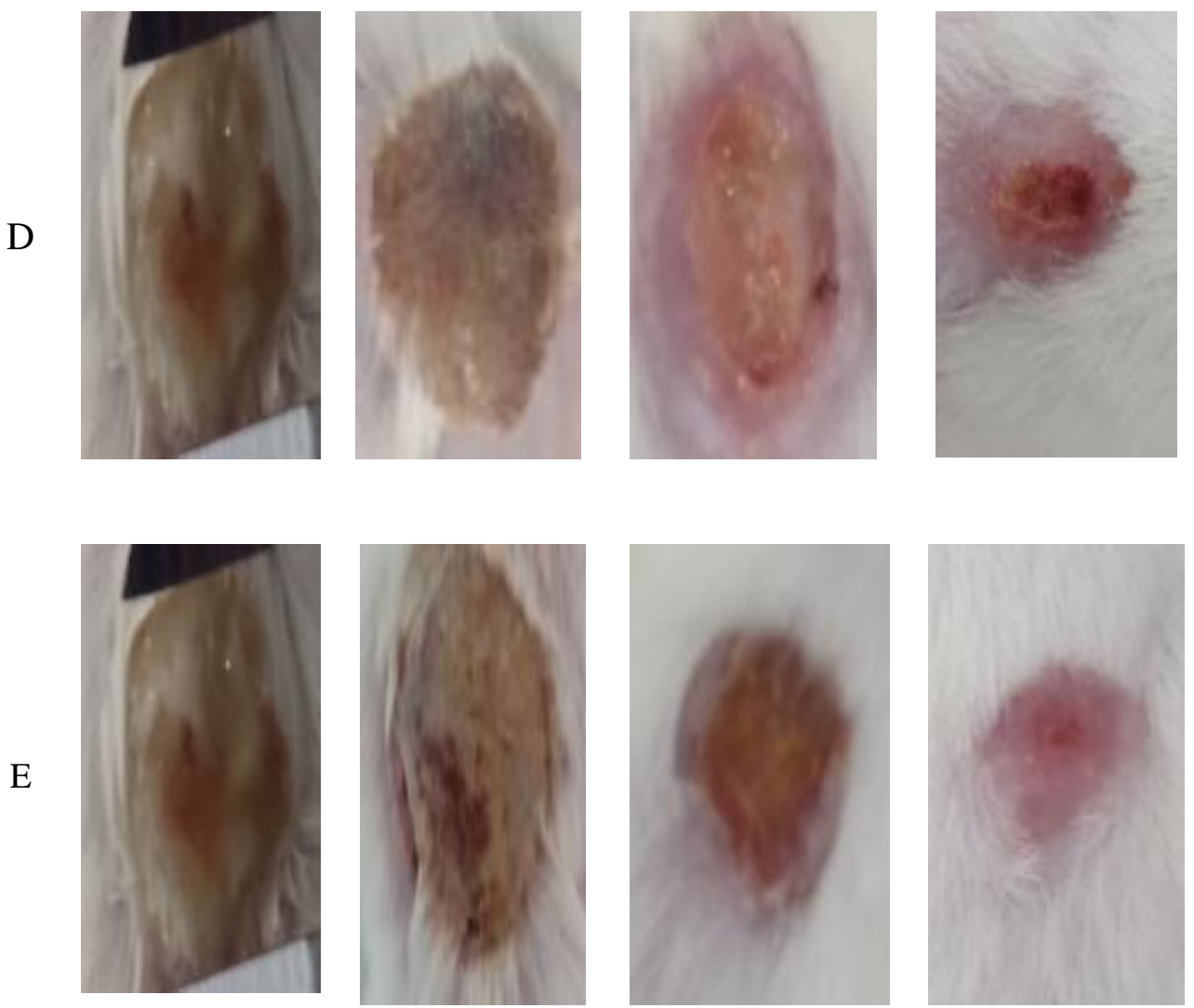

Gambar 5. Hasil Perubahan Kondisi Luka Bakar ( $\mathrm{A}=$ Kontrol negative, $\mathrm{B}=\mathrm{Basis}$, $\mathrm{C}=\mathrm{F} 1(5 \%), \mathrm{D}=\mathrm{F} 2(10 \%), \mathrm{E}=\mathrm{F} 3(15 \%)$.

Tabel 6. Hasil Pengukuran Pengurangan Diameter dan Persentase Penyembuhan Luka Bakar

\begin{tabular}{ccccc}
\hline \multirow{2}{*}{ Formula } & \multicolumn{4}{c}{ Rata-rata Pengurangan Diameter $(\mathrm{cm})$ Luka Hari Ke- } \\
\cline { 2 - 5 } & 0 & 6 & 15 & 21 \\
\hline $\begin{array}{c}\text { Kontrol Negatif } \\
\pm \text { SD }\end{array}$ & $1,50 \pm 0,0000$ & $1,35 \pm 0,0125$ & $1,15 \pm 0,0095$ & $0,84 \pm 0,00230$ \\
$(\%$ Penyembuhan $)$ & $(0)$ & $(10)$ & $(23,3)$ & $(44)$ \\
Basis \pm SD & $1,50 \pm 0,0000$ & $1,29 \pm 0,0115$ & $1,07 \pm 0,0081$ & $0,59 \pm 0,0095$ \\
$(\%$ Penyembuhan $)$ & $(0)$ & $(14)$ & $(28,9)$ & $(60,6)$ \\
F1 $(5 \%) \pm$ SD & $1,50 \pm 0,0000$ & $1,26 \pm 0,0115$ & $0,80 \pm 0,0095$ & $0 \pm 0,0000$ \\
$(\%$ Penyembuhan $)$ & $(0)$ & $(16)$ & $(46,6)$ & $(100)$ \\
F2 $(10 \%) \pm$ SD & $1,50 \pm 0,0000$ & $1,20 \pm 0,0057$ & $0,44 \pm 0,0493$ & $0 \pm 0,0000$ \\
$(\%$ Penyembuhan $)$ & $(1)$ & $(20)$ & 70,6 & $(100)$ \\
F3 (15\%) \pm SD & $1,50 \pm 0,0000$ & $1,14 \pm 0,0095$ & $0 \pm 0,0000$ & $0 \pm 0,0000$ \\
$(\%$ Penyembuhan $)$ & $(0)$ & $(24)$ & $(100)$ & $(100)$ \\
\hline
\end{tabular}




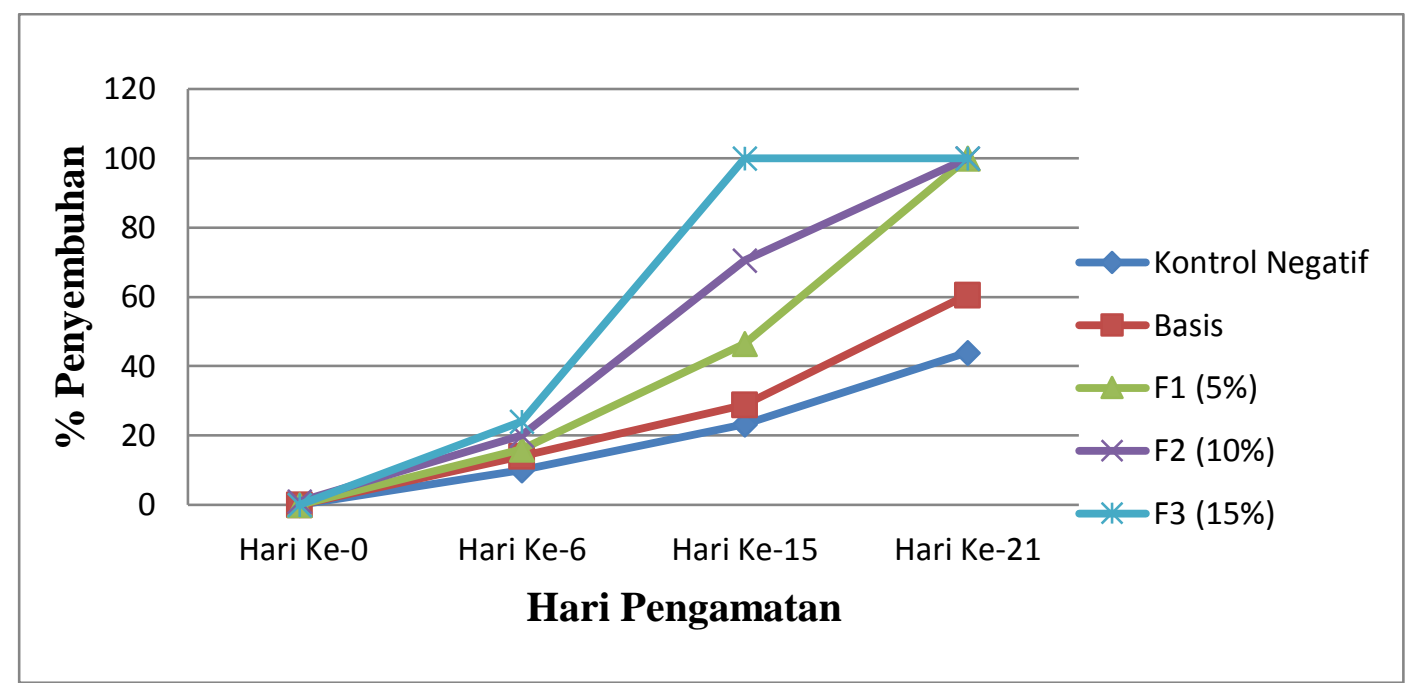

Gambar 6. Persentase Penyembuhan Luka Bakar

Analisis statistik Analysis of Varience (ANOVA) dua arah untuk melihat signifikansi $(\mathrm{p}>0,05)$ dan dilanjutkan dengan uji Tukey untuk melihat kelompok mana yang memiliki perbedaan signifikan, diperoleh bahwa pengurangan diameter luka bakar dari semua formulasi (F1, F2 dan F3) berbeda signifikan dengan kontrol negatif dan F3 (15\%) berbeda signifikan dengan F1 (5\%) dan F2 (10\%). Alasan penggunaan uji ANOVA dua arah karena data terdiri dari variabel terikat dan dua variabel bebas, yang mana variabel terikat yaitu diameter luka bakar sedangkan variabel bebasnya yaitu perbedaan konsentrasi pada F1, F2, F3 dan lama waktu perlakuan mengoleskan sediaan ke mencit. Adapun tujuan dari ANOVA dua arah yaitu untuk melihat perbedaan dari 5 kelompok pengujian dan waktu terhadap pengurangan diameter luka bakar menggunakan sediaan emulgel minyak ikan gabus dengan berbagai konsentrasi.

Hasil uji ANOVA dilanjutkan dengan uji Tukey. Uji Tukey digunakan untuk melihat kelompok perlakuan yang memiliki efek sama atau berbeda antara satu dengan lainnya.Berdasarkan hasil uji Tukey diperoleh hasil bahwa diameter luka bakar pada semua kelompok formula (FI, FII dan FIII) berbeda signifikan $(\mathrm{p}<0,05)$ terhadap kelompok kontrol negatif dan basis. Hal tersebut mengindikasikan bahwa semua formula memiliki efektivitas penyembuhan luka. Perbedaan signifikan antara kelompok negatif dan basis dengan semua kelompok formula (F1, F2 dan F3) tersebut dilihat dari parameter rata-rata penutupan diameter luka dan rata-rata peresentase penyembuhan luka di mana kelompok negatif dan basis diameter penutupan luka lebih kecil karena waktu lebih lama dibanding perlakuan. Dari pengamatan yang telah dilakukan menunjukkan bahwa pada hari ke 15 pengolesan sediaan emulgel minyak ikan gabus didapatkan hasil rata-rata pengurangan diameter luka bakar yaitu basis $=1,07 \mathrm{~cm}$, kontrol negatif $=1,15 \mathrm{~cm} \mathrm{~F} 1=0,80 \mathrm{~cm}, F 2=0,44 \mathrm{~cm}, F 3=0 \mathrm{~cm}$, dari hasil terlihat bahwa $\mathrm{F} 3$ pada hari ke 15 telah memberikan penutupan luka secara optimal yang berarti bahwa sediaan emulgel minyak ikan gabus pada F1, F2 dan F3 mampu mengurangi diameter luka bakar dibandingkan perlakuan dengan basis maupun penyembuhan secara alami. Perbedaan signifikan antara F3 dengan F2 dan F1,diameter luka bakar dimana F3 lebih tinggi pengurangan diameter luka bakarnya. Berdasarkan persentase rata-rata penyembuhan luka persentase pengurangan diameter luka bakar pada F3 lebih cepat, hal tersebut karena F3 mengandung konsentrasi minyak ikan gabus yang paling tinggi yaitu $15 \%$ sedangkan pada F1 mengandung minyak ikan gabus sebanyak 5\% dan F2 mengandung minyak ikan gabus sebanyak $10 \%$.

\section{KESIMPULAN}

Berdasarkan hasil uji stabilitas fisik dapat disimpulkan bahwa emulgel minyak ikan gabus pada konsentrasi F1=5\%, F2=10\% dan F3=15\% memiliki stabilitas fisik yang baik. Dari hasil uji statistik 
ANOVA yang dilanjutkan dengan uji Tukey didapatkan hasil adanya perbedaan diantara perlakuan terhadap pengurangan diameter luka bakar. Formula yang memiliki kemampuan penyembuhan luka bakar yang lebih cepat dengan persentase penyembuan luka 100\% pada hari ke-15 adalah F3 dengan konsentrasi minyak ikan gabus yang paling tinggi yaitu 15\%sedangkan F1 dan F2 baru mecapai 100\% penyembuhan luka pada hari ke-21.

\section{UCAPAN TERIMAKASIH}

Ucapan terimakasih penulis ucapkan kepada seluruh pihak yang telah membantu penyelesaian penelitian ini, khususnya kepada Sekolah Tinggi Ilmu Farmasi (STIFAR) Riau yang telah membiayai keseluruhan pelaksanaan penelitian ini dan umumnya kepada pihak Laboratorium Farmasetika, Farmakologi dan Teknologi Farmasi yang telah memfasilitasi keseluruhan proses penelitian ini.

\section{DAFTAR PUSTAKA}

Abdurrahmat, A. S. 2014. Luka Peradangan dan Pemulihan. Jurnal Entropi, 9 (1)

Agoes, G. 2012. Sediaan Farmasi Likuida-Semisolida (SFI-7). Penerbit ITB :Bandung

Allen, L. V. 2002. The Art, Science and Technology of Pharmaceutical Compounding, Second Edition. American Pharmaceutical Association. Washington D.C.

Anonim. 1995. Farmakope Indonesia Edisi IV. Departemen Kesehatan Republik Indonesia : Jakarta.

Anonim. 2014. Farmakope Indonesia EdisiV. Departemen Kesehatan Republik Indonesia : Jakarta.

Ansel, H.C. 2008. Pengantar Bentuk Sediaan Farmasi Ed.IV. UI Press : Jakarta

Asmillyas. Handayani, F. Afriani, T dan Suardi, M. 2017. Formulasi Gel Minyak Ylang-Ylang dan Uji Daya Antibakteri Terhadap Bakteri Penyebab Jerawat. Jurnal Ipteks Terapan, 11(13): 246-25.

Collins, N., and Sulewski, C. 2011. Ostomy Wound Management. 10-13

Dhawan, S. Medhi, B. dan Chopra, S. 2009. Formulation and Evaluation of Diltiazem Hydrochloride Gels for The Treatment of Anal Fissures. Scientia Pharmaceutica. 7(7): 465-482.

Garg, A.Aggarwal, S. Garg and A. K. Sigla. 2002. Spreading of Semisolid Formulation: An Update. Pharmaceutical Tecnology : 84-102.

Gusdi, O. (2012). Formulasi sediaan gel ekstrak ikan gabus (Channa striata) sebagai obat luka sayat. Skripsi. Program Studi Farmasi, Fakultas Kedokteran, Universitas Tanjungpura Pontianak

Jawetz, E. Melnick JL dan Adelberg EA. 2012. Mikrobiologi Kedokteran edisi 25. EGC Penerbit Buku Kedokteran : Jakarta.

Kumar. V. Cotran. 2007. Buku Ajar Patologi Anatomi. EGC 7(2): 367-378 : Jakarta.

Lachman, L. Lieberman, H. A and Kanig, J. L. 1994. Teori dan Praktek Farmasi Industri, edisi III. Universitas Indonesia Press : Jakarta.

Manan, A. 2007. Pharmacognosy and Pharmacology of Haruan (Channa striatus) a medicinal fish with wound healing properties. Boletin Latinoamericano y del Caribe de Plantas Medicinales y Aromaticas, 6(3): 52-60.

Martin A.J. Swarbrick, J. Cammarta, A. 1993. Farmasi Fisik : Dasar-dasar Kimia Fisik Dalam Ilmu Farmasetik. Jilid 2, Ed. 3. Penerbit UI : Jakarta 
Moenadjat, Y. 2003. Luka Bakar Pengetahuan Klinik Praktis Edisi II. Fakultas Kedokteran UI : Jakarta.

Nagori, B. D dan Solanki, R. 2011.Role Of Medicinal Plants In Wound Healing. Research Journal Of Medicinal Plants. 5(4): 392-405.

Pusponegoro A.D. 2005. Buku Ajar Ilmu Bedah Edisi ke-2. Penerbit Buku Kedokteran EGC 66-88 : Jakarta.

Sabale, P. Bhimani, B. Prajapati, C. Sabale, V. 2012. An Overview of Medicinal Plants as Wound Healers. Journal Application Pharmaceutical Science. 2(11): 143-150.

Sinambela, H.Y. (2012). Optimasi Formulasi Sediaan Salep Minyak Ikan Gabus (Channa striata Bloch) Sebagai Obat Luka Sayat dengan Metode Simplex Lattice Design. Skripsi. Program Studi Farmasi, Fakultas Kedokteran Universitas Tanjungpura Pontianak.

Singla, V. Saini, S. Joshi, B. dan Rana, A.C. 2012. Emugel: A New Platform For Topical Drug Delivery.International Journal of Pharma and Bio Science. 3(2): 485-497.

Sinko, Patrick J. (2006). Martin Farmasi Fisika dan Ilmu Farmasetika, Edisi 5, Penerbit Buku Kedokteran, Jakarta.

Sumoza, N. S. Efrizal dan Rahayu, R. 2014. Pengaruh Gambir (Uncaria gambir R.) Terhadap Penyembuhan Luka Bakar pada Mencit Putih (Mus musculus L.) Jantan. Jurnal Biologi Universitas Andalas. 3(4): 14-19.

Tranggono, R.I. dan Latifah, F. 2007. Buku Pegangan Ilmu Pengetahuan Kosmetik. Gramedia Pustaka Utama: Jakarta.

Tri, NY. Effionora, A. Fadlina, CS. 2016. Formulasi Emulgel yang Mengandung Ekstrak Etanol Daun Binahong (Anredera cordifolia(Ten.) Steenis) dan Uji Aktivitasnya terhadap Propionibacterium acnes secara In Vitro. Jurnal Kefarmasian Indonesia. 6(2): 89-97.

Voigt. 1994. Buku Ajar Teknologi Farmasi. Diterjemahkan oleh Soendani Noeroto S. Yogyakarta: UGM Press.

Yanti, R. 2012. Pengaruh Nutrisi Ikan Gabus Terhadap Penambahan Berat Badan Balita Gizi Kurang. Skripsi. Riau: Universitas Muhammadiyah Riau. 